\title{
TAWAZUN
}

JURNAL PENDIDIKAN ISLAM

Vol. 11, No. 2, Desember 2018, e-ISSN: 2654-5845, hlm. 176-189

\section{IMPLEMENTASI GAYA KEPEMIMPINAN NABI MUSA A.S DALAM PENDIDIKAN KARAKTER}

\author{
Andi Noor Fitrah Syarifin, Didin Hafidhuddin, Abdul Hayyie Al-Kattani \\ Universitas Ibn Khaldun Bogor \\ sharefine682@gmail.com
}

\begin{abstract}
ABSTRAK
Artikel ini bertujuan untuk membahas gaya kepemimpinan salah satu dari lima nabi yang memperoleh predikat Ulul 'Azmi, yaitu Nabi Musa a.s. dalam Al-Quran dan penerapannya dalam pendidikan karakter. Metode yang digunakan dalam penulisan yaitu studi pustaka (library research) dengan pendekatan tafsir tematik (tafsir maudhu'i). Dari hasil pembahasan bahwa gaya kepemimpinan Nabi Musa a.s di dalam Al-Quran yaitu bersyukur atas karunia Allah dan mengajak kaumnya untuk bersyukur, selalu bersabar dalam menghadapi cobaan, penuh motivasi, optimis, dan pantang menyerah. Implementasi dalam pendidikan karakter dengan cara: 1. mengajarkan bahwa Allah adalah sumber segala kenikmatan yang diperoleh, dan selalu berbahagia kepada Allah atas nikmat yang diperoleh. Setelah itu mengajarkan kepada anak agar selalu mengucap syukur dengan lisan dan menggunakan nikmat yang digunakan untuk kebaikan dan bukan untuk kemaksiatan. 2. terus meyakinkan bahwa di dalam setiap kesabaran seorang muslim, pertolongan Allah pasti akan datang dan setiap kesabaran akan mendatangkan hasil yang melegakan hati. 3. mengadakan berbagai kegiatan yang memicu motivasi dan rasa pantang menyerah seperti berbagai perlombaan, permainan pertandingan, organisasi sehingga terbiasa untuk saling bersaing secara sehat dan penuh motivasi untuk maju. Anak-anak didik pun akan terbiasa untuk menghadapi berbagai tantangan yang ada dan tidak akan mudah menyerah dalam menghadapinya.
\end{abstract}

Kata kunci: gaya kepemimpinan; Nabi Musa a.s; pendidikan karakter

\section{Pendahuluan}

Al-Quran sebagaimana kita ketahui bersama, di dalamnya terkandung berbagai macam panduan hidup baik dari segi ekonomi, politik, sosial, maupun pendidikan. Dan salah satu hal penting yang mendapatkan porsi besar di dalam Al-Quran untuk menjadi panduan umat manusia adalah pelajaran dari sejarah umat terdahulu yang terkandung di dalam Al-Quran. Dengan memahami sejarah umat terdahulu, setiap generasi mengetahui apa saja harus ditiru dan diamalkan dari hal positif generasi yang lampau dan apa saja yang harus ditinggalkan dan dihindari dari segala hal negatif masa lalu. 
Tentu saja informasi yang disampaikan al-Quran dan penjelasan yang diberikan para ahli sejarah mengenai kisah para rasul berikut permasalahan yang dihadapinya bukan hanya sebagai pengetahuan atau wacana, melainkan untuk digali pesan ajaran moral yang terkandung di dalamnya; serta dijadikan bahan renungan untuk kemungkinan diterapkan pada masa selanjutnya. Dengan demikian keimanan yang demikian itu dapat menimbulkan dampak psikologis edukatif bagi umat manusia. (Nata, 2002)

Salah satu Nabi dan Rasul Allah yang diabadikan kisah dan sejarahnya di dalam AlQuran adalah Musa a.s. Nabi Musa a.s adalah salah satu dari nabi yang bergelar Ulul Azmi yaitu gelar yang disematkan kepada nabi yang terkenal dengan keteguhan hatinya, kesabaran dalam menghadapi kaumnya, dan ketabahan dalam menghadapi cobaan dan ujian dalam berdakwah. Sebagaimana yang dijelaskan di dalam Q.S AlAhqaaf: 35:

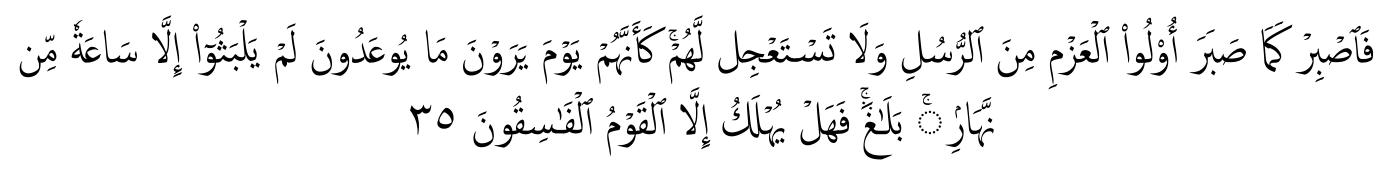

“Maka bersabarlah kamu seperti orang-orang yang mempunyai keteguhan hati dari rasul-rasul telah bersabar dan janganlah kamu meminta disegerakan (azab) bagi mereka. Pada hari mereka melihat azab yang diancamkan kepada mereka (merasa) seolah-olah tidak tinggal (di dunia) melainkan sesaat pada siang hari. (Inilah) suatu pelajaran yang cukup, maka tidak dibinasakan melainkan kaum yang fasik"

Dengan demikian memahami sejarah tentang kisah Nabi Musa A.S dalam memimpin dan mengayomi kaumnya untuk bekal dalam mendidik karakter perlu untuk digalakkan di mana Nabi Musa berusaha membebaskan Bani Israel dari kekejaman Firaun atas perintah Allah S.W.T dan membimbing mereka di dalam ketaatan dan keimanan kepada Allah.

\section{KaJian Literatur}

\section{A. Sejarah Singkat Nabi Musa}

Di dalam buku Ensiklopedia Pengetahuan Al-Quran dan Hadits dijelaskan bahwa Nabi Musa a.s. adalah seorang Nabi yang menyampaikan Hukum Taurat. Nabi Musa a.s. adalah anak dari Amran bin Kehat dari suku Lewi, anak Yakub bin Ishaq. la diangkat menjadi nabi sekitar tahun 1450 SM. Ibu Nabi Musa a.s. bernama Yokhebed. Ayah dan Ibu Nabi Musa a.s., Amran dan Yokhebed berasal dari suku yang sama yaitu suku Lewi. Musa sendiri memiliki dua orang kakak yaitu Miryam dan Harun a.s. Dan Nabi Musa sendiri memiliki 2 orang anak yaitu Gersom dan Eliezer. (Kilmah, 2013) 
Nabi Musa a.s. sendiri adalah seorang yang diutus oleh Allah untuk pergi membebaskan bangsa Israel dari perbudakan Mesir, dan menuntun mereka pada tanah perjanjian yang dijanjikan Allah kepada Nabi Ibrahim a.s yaitu tanah Kanaan. (Kilmah, 2013)

Peristiwa kelahiran Nabi Musa a.s. berada di tengah-tengah kesulitan besar yang dihadapi orang-orang Israel. Yaitu pada masa-masa penindasan orang-orang Israel oleh Firaun dan turunnya perintah untuk membunuh setiap bayi yang lahir dari kalangan Israel. Setelah melahirkan, Ibunda Musa merasa cemas atas keselamatan bayinya. Namun, kehendak Allah berkata lain. Dia mengilhami pikiran ibunda Musa untuk memasukkan bayinya ke dalam peti lalu menghanyutkannya di sungai Nil. Allah memberi ketenangan kepada ibunda Musa untuk tidak berduka dan cemas, karena sejatinya Dia akan memulangkan Musa ke pangkuannya dan menyampaikan kepadanya bahwa Musa a.s akan diangkat sebagai Rasul-Nya. (Halim, 2011)

Josephus Flavius, sejarawan terkemuka Yahudi yang hidup pada abad ke-6 M menyampaikan bahwa salah satu penulis Mesir kuno menceritakan bahwa para peramal menyampaikan ramalannya kepada Firaun bahwa pada zamannya akan lahir seorang bayi laki-laki dari keturunan Israel yang suatu hari akan menumbangkan kekuasaannya. Ramalan tersebut mendatangkan rasa takut pada diri Firaun, dan karena ketakutan itulah yang menjadi alasan kenapa ia mengeluarkan perintah agar setiap bayi laki-laki yang lahir dari wanita Israel tidak boleh dibiarkan hidup. (Halim, 2011)

Dari penjelasan singkat tentang sejarah Nabi Musa a.s di atas, dapat dilihat bahwa Musa sejak lahir memang berada di bawah bayang-bayang ancaman dan kezaliman Firaun yang diarahkan kepada Bani Israel yang merupakan bangsa dan saudara Nabi Musa a.s. Maka pengangkatan Nabi Musa sebagai Nabi dan Rasul Allah yang bertugas untuk memimpin dan mengayomi Bani Israel bukanlah hal muda karena harus berhadapan dengan kekuasaan dan rezim Firaun yang terkenal dengan kekejamannya.

\section{B. Gaya Kepemimpinan}

Organisasi adalah sistem kegiatan terkoordinasi dari kelompok yang bekerja sama mengarah pada tujuan bersama di bawah kewenangan dan kepemimpinan. (Kartono, 2010) Sebuah organisasi baik itu skala kecil maupun skala besar tidak akan pernah bisa jalan tanpa adanya seseorang yang menjadi pemimpin. Seorang pemimpin memainkan peran dan faktor yang sangat penting dalam kemajuan maupun kemunduran suatu organisasi. Dalam hal ini gaya kepemimpinan seorang pemimpin sangat menentukan bagaimana jalannya organisasi atau perkumpulan tersebut.

Terkait gaya kepemimpinan yang harus dimiliki oleh seorang pemimpin dalam menentukan bagaimana arah dan jalannya sebuah organisasi, Paul J. Meyer 
menjelaskan bahwa seorang pemimpin harus memiliki lima pilar yang harus mampu dilaksanakan dengan baik oleh seorang pemimpin. Lima pilar tersebut antara lain: (Meyer, 2008)

1. Menajamkan Pikiran.

Dalam hal ini, seorang pemimpin dan anggotanya harus mempunyai pikiran yang fokus dan tajam terkait visi dan misi dari organisasi yang dijalankan.

2. Menyusun rencana aksi yang tertulis.

Menyusun dan menuliskan rencana yang akan dikerjakan sangat penting untuk menjaga komitmen organisasi untuk mencapai tujuan yang diharapkan.

3. Membangkitkan hasrat dan semangat.

Peran seorang pemimpin dalam hal ini sangat dibutuhkan. Karena pemimpin yang sukses harus mengetahui bahwa kunci untuk mengembangkan potensi bawaan atau anggota terletak di dalam mengembangkan hasrat yang penuh semangat untuk pengembangan potensi diri sebagai anggota tim atau organisasi.

4. Keyakinan dan kepercayaan.

Seorang pemimpin harus mengembangkan sikap percaya dalam memberdayakan anggotanya dan membangun rasa saling percaya di antara anggota tim dan organisasi.

5. Memupuk komitmen dan tanggung jawab

Pada pilar terakhir inilah seorang pemimpin harus lebih tinggi di dalam memiliki rasa komitmen dan tanggung jawab di dalam menjalankan segala rencana aksi yang telah ditulis atau diprogramkan. Agar anggota tim yang berada di bawah kepemimpinannya mempunyai rasa semangat dan idealisme yang sama.

\section{Pengertian Pendidikan Karakter}

Kata karakter menurut Kamus Besar Bahasa Indonesia (2008) berarti; sifat-sifat kejiwaan, akhlak atau budi pekerti yang membedakan seseorang dari yang lain. Sedangkan karakter menurut Pusat Bahasa Depdiknas memiliki makna; bawaan hati, jiwa, kepribadian, budi pekerti, perilaku, personalitas, sifat, tabiat, temperamen, dan watak.

Mohamad Ali dan Mohammad Asrori menjelaskan bahwa perbedaan-perbedaan karakter yang terjadi disebabkan manusia diciptakan secara unik, berbeda satu sama lain, dan tidak satu pun yang memiliki ciri-ciri persis sama meskipun mereka itu kembar identik. Setiap individu pasti memiliki karakteristik yang berbeda dengan individu 
lainnya. Perbedaan individual ini merupakan kodrat manusia yang bersifat alami. Berbagai aspek dalam diri individu berkembang melalui cara yang bervariasi sehingga menghasilkan perubahan karakteristik individual yang bervariasi pula. (Ali \& Asrori, 2017)

Para pakar psikologi juga mendefinisikan karakter sebagai sifat, watak atau tabiat seseorang yang telah dimiliki sejak lahir dan merupakan sesuatu yang membedakan setiap individu. Karakter juga didefinisikan sebagai pembawaan dari dalam yang dapat digunakan untuk membentuk tingkah laku, sikap dan tabiat yang benar. (Rosyadi, 2013)

Adapun makna berkarakter adalah; berkeperibadian, berperilaku, bersifat, bertabiat, dan berwatak. Jadi, dapat dikatakan bahwa individu yang berkarakter adalah seseorang yang berusaha melakukan hal-hal yang terbaik terhadap Allah S.W.T. (Syafri, 2014)

Melihat definisi karakter di atas yang menjurus kepada sifat-sifat kejiwaan yang diridai Allah, sudah sepatutnya kita sebagai seorang manusia untuk meletakkan perhatian terhadap karakter di dalam prioritas utama di dalam dunia pendidikan. Mengingat bahwa fenomena permasalahan yang dihadapi dunia pendidikan masa kini, khususnya di Indonesia, lebih kepada permasalahan karakter dan kejiwaan. Kenakalan remaja, tawuran antar pelajar, sampai kepada praktik KKN (Korupsi, Kolusi, dan Nepotisme) para elite pejabat, merupakan fenomena umum yang menunjukkan rendahnya mutu karakter oknum pelakunya.

Ulil Amri Syafri menjelaskan bahwa di dalam pembahasan tentang pendidikan karakter di Indonesia, ada dua aspek yang kurang mendapat perhatian dari para pemerhati pendidikan, yaitu aspek agama dan aspek budaya bangsa. Kedua aspek tersebut penting diteliti dan digali karena sangat berpengaruh dalam menentukan hasil didikan karakter seorang peserta didik. Karakter seorang manusia sangat erat kaitannya dengan agama, lingkungan, dan budaya di mana ia tumbuh dan dibesarkan. Karena itu, sangat disayangkan jika para pemerhati pendidikan Indonesia berkaca bahkan melakukan studi banding penerapan pendidikan karakter pada bangsa lain seperti Amerika Serikat, Jepang, Cina, Korea, dan negara lainnya. Perbandingan itu akan lebih baik jika dilakukan setelah para pemerhati pendidikan Indonesia menemukan dan merumuskan pendidikan karakter dalam perspektif bangsa. Sehingga studi banding yang dilakukan benar-benar efektif karena ada yang dibandingkan. (Syafri, 2014)

Penjelasan di atas tentang pentingnya aspek agama di dalam pembentukan karakter ke arah yang positif, sangat diperhatikan di dalam ajaran agama Islam demi terbentuknya karakter seorang muslim yang baik atau Syakhshiyyah Islamiyyah. Dalam hal ini, Ismail Yusanto dkk. menjelaskan bahwa seorang muslim yang memegang teguh 
karakter keislaman yang mumpuni, tampak dari cara berpikir (aqliyyah) dan cara bersikapnya (nafsiyyah) yang senantiasa dilandaskan pada ajaran Islam. (Syafri, 2014)

M. Ismail Yusanto dkk. menambahkan bahwa pada prinsipnya ada tiga langkah metode pembentukan dan pengembangan karakter seorang muslim:

1. Menanamkan Aqidah Islam dengan metode yang menggugah akal, menggetarkan jiwa dan menyentuh perasaan

2. Mendorong untuk senantiasa menegakkan bangunan cara berpikir dan perilakunya di atas Aqidah dan syariah Islam yang telah menghunjam kuat dalam hatinya.

3. Mengembangkan kepribadian dengan cara bersungguh-sungguh mengisi pemikiran dengan tasqofah Islamiyyah dan mengamalkannya dalam seluruh aspek kehidupannya dalam rangka melaksanakan ketaatan kepada Allah SWT.

Ke sanalah pendidikan yang membentuk karakter seorang muslim diarahkan. Pendidikan harus mampu menanamkan Aqidah Islam, cara berpikir yang Islami dan kebiasaan berperilaku sesuai aturan Islam.(Yusanto, 2011)

\section{Metodologi Penelitian}

Penelitian ini menggunakan pendekatan Kualitatif, karena sifat data yang dikumpulkan adalah kualitatif. Sedangkan sumber data utama penelitian ini berupa kitab-kitab Tafsir Al-Quran.

Dalam hal ini, penulis membahas tafsiran dari ayat-ayat dalam Al-Quran tentang kepemimpinan Nabi Musa di dalam mengayomi kaumnya ketika sedang berada di bawah penindasan dan kezaliman Firaun.

\section{Hasil dan Pembahasan}

\section{A. Ayat-ayat tentang kepemimpinan Nabi Musa a.s dan Penjelasan Tafsirnya.}

1. Q.S. Ibrahim: 6

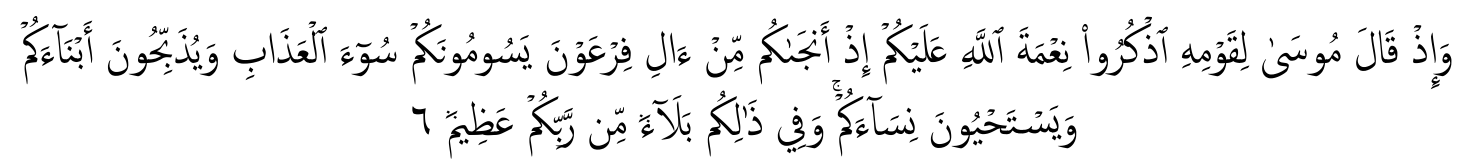

“Dan (ingatlah), ketika Musa berkata kepada kaumnya: "Ingatlah nikmat Allah atasmu ketika Dia menyelamatkan kamu dari (Firaun dan) pengikut-pengikutnya, 
mereka menyiksa kamu dengan siksa yang pedih, mereka menyembelih anak-anak laki-lakimu, membiarkan hidup anak-anak perempuanmu; dan pada yang demikian itu ada cobaan yang besar dari Tuhanmu"

Sayyid Quthub menjelaskan dalam ayat ini bahwa Nabi Musa a.s memperingatkan kaumnya dengan nikmat Allah atas mereka. Yakni kenikmatan selamat dari pedihnya siksa yang dulu mereka terima dari Firaun dan para pengikutnya. Mereka alami siksaan itu dengan penderitaan panjang yang tiada putus-putusnya. Di antara bentuk siksaan yang sangat nyata adalah penyembelihan anak laki-laki mereka dan dibiarkannya hidup anak wanita. Hal ini dilakukan Firaun dengan tujuan:

a. Untuk mencegah terhimpunnya kekuatan yang dapat membentengi mereka

b. Melanggengkan kelemahan dan kehinaan mereka.

Keselamatan yang diberikan Allah dari kondisi yang demikian itu merupakan kenikmatan yang harus diingat untuk disyukuri. Adapun cobaan yang diberikan Allah kepada Bani Israel dimaksudkan untuk menguji kesabaran, keteguhan, ketahanan dan kebulatan tekad untuk menyelesaikannya. Kesabaran bukan hanya kesanggupan menanggung kehinaan dan siksaan. Akan tetapi, kesabaran mempunyai tujuan:

a. Kesanggupan menanggung siksaan tanpa adanya kerapuhan dan kekalahan jiwa

b. Kontinuitas tekad dan semangat untuk menyelesaikan tugas

c. Kesiapan diri untuk berada dalam wajah kezaliman dan kesewenang-wenangan. (Quthb, 2008)

Dari penjelasan Tafsir Sayyid Quthub di atas terkait Surat Ibrahim ayat 6, dapat disimpulkan bahwa Nabi Musa a.s. di dalam memimpin kaumnya mempunyai gaya kepemimpinan yang bertekad kuat untuk menjalani segala rintangan yang ada, kesabaran tinggi dalam menghadapinya dan rasa syukur atas segala nikmat yang diberikan Allah kepadanya dan kepada kaumnya.

Jika dikorelasikan dengan teori dari Paul J. Meyer tentang lima pilar di dalam gaya kepemimpinan, Nabi Musa di dalam ayat ini memiliki semangat dan hasrat dalam untuk menghadapi cobaan yang dihadapinya dan kaumnya. semangat dan hasrat menghadapi cobaan dari Firaun berusaha ditularkan Musa kepada kaumnya dengan mengingatkan nikmat yang telah Allah anugerahkan kepada mereka.

2. Q.S. As-Syuara: 16-17

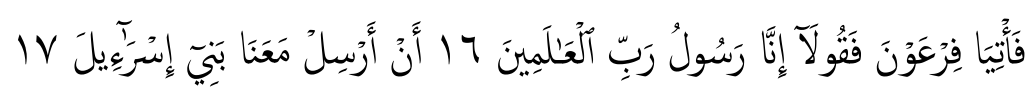

“Maka datanglah kamu berdua kepada Firaun dan katakanlah olehmu: 
"Sesungguhnya Kami adalah Rasul Tuhan semesta alam. lepaskanlah Bani Israil (pergi) beserta kami"

Dalam Tafsir lbnu Katsir dijelaskan bahwa dalam ayat ini Musa menjelaskan kepada Firaun bahwa dia adalah utusan atau Rasul Tuhan Semesta Alam yaitu Allah S.W.T. dan Musa meminta kepada Firaun untuk melepaskan Bani Israil dari cengkeraman, perbudakan, tawanan, dan intimidasi Firaun yang telah berlangsung sangat lama. Karena sesungguhnya mereka Bani Israil adalah merupakan hamba-hamba Allah yang beriman dan golongan-Nya yang ikhlas. (Ar-rifa'i, 1999)

Kepemimpinan Musa dalam ayat ini dengan jelas sangat terlihat. Ketegasannya sebagai utusan Allah dalam memperjuangkan hak kebebasan Bani Israel dari penjajahan Firaun, tidak kendor sedikit pun walaupun secara jelas Musa sama sekali tidak memiliki kekuatan baik politik maupun militer untuk menghadapi kekuatan Firaun.

Kejelasan dan ketegasan visi dan misi Musa untuk menyelamatkan kaumnya disertai dengan keyakinan yang bukan hanya terhadap pertolongan Allah tetapi juga keyakinan terhadap kepercayaan kaumnya kepadanya membuat Musa berani tampil langsung ke hadapan Firaun sebagai utusan Allah dan pemimpin Bani Israel.

3. Q.S. al-A'raf: 128

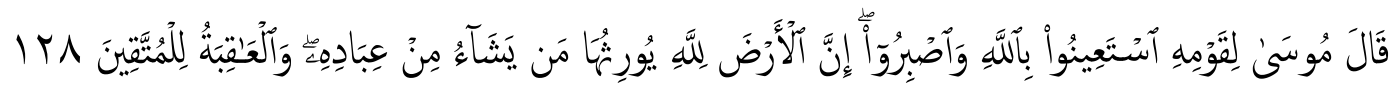

Musa berkata kepada kaumnya: "Mohonlah pertolongan kepada Allah dan bersabarlah; sesungguhnya bumi (ini) kepunyaan Allah; dipusakakan-Nya kepada siapa yang dihendaki-Nya dari hamba-hamba-Nya. Dan kesudahan yang baik adalah bagi orang-orang yang bertakwa"

Buya Hamka dalam Tafsir Al-Azhar menjelaskan tentang ayat ini bahwa Musa sebagai pemimpin Bani Israil menasihati kaumnya yang telah cemas itu. Mereka mesti memperkuat benteng iman kepada Allah, memperteguh kepercayaan, sabar dan tenang, jangan lekas cemas mendengar berita seperti demikian. Karena meskipun Firaun telah mengatakan bahwa sangat berkuasa melakukan apa yang dia ingini terhadap Bani Israil, namun yang mempunyai bumi ini adalah Allah. Di atas kekuasaan Firaun ada kekuasaan Allah. Sebab itu hendaklah Bani Israil membulatkan ketundukan kepada Allah itu sendiri. Bumi akan diwariskan Allah kepada barang siapa yang Dia kehendaki. Inilah keyakinan pertama yang wajib ditanamkan, dan keyakinan kedua adalah bahwa akibat atau kemenangan terakhir akan diberikan Allah kepada orang yang bertakwa. Yaitu takwa dengan seluas-luas artinya. Sebab takwa itulah yang akan membuat jiwa menjadi lebih kebal menghadapi segala kesulitan. (Hamka, 2003) 
Penjelasan tafsir Buya Hamka di atas menggambarkan bagaimana seorang Musa membangkitkan semangat kaumnya yang sedang dilanda kesusahan akibat kekejaman Firaun. Musa hadir di tengah-tengah kaumnya untuk memberikan motivasi kepada kaumnya agar memohon pertolongan hanya kepada Allah dan bersabar, dan bumi beserta isinya adalah milik Allah yang akan Dia wariskan kepada siapa yang dia kehendaki. Gaya kepemimpinan Musa dalam ayat ini tergambarkan dalam kemampuannya untuk menaikkan motivasi, keyakinan akan pertolongan Allah dan moril kaumnya yang memang sedang turun dikarenakan kekejaman dan kezaliman Firaun.

4. Q.S. Al-A'raf: 129

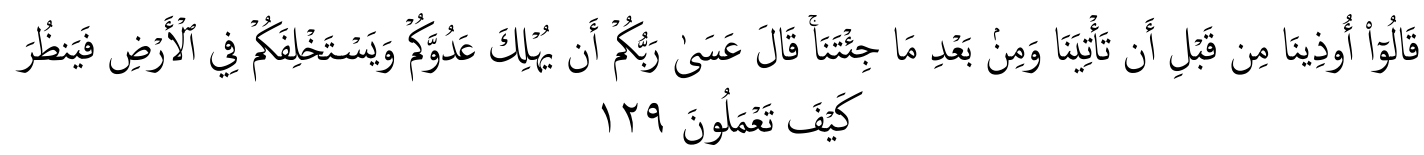

Kaum Musa berkata: "Kami telah ditindas (oleh Firaun) sebelum kamu datang kepada kami dan sesudah kamu datang. Musa menjawab: "Mudah-mudahan Allah membinasakan musuhmu dan menjadikan kamu khalifah di bumi(Nya), maka Allah akan melihat bagaimana perbuatanmu

Hamka menilai bahwa suka mengeluh memang sudah menjadi watak Bani Israel. Keluhan itu dijawab oleh Musa dengan berkata " "Mudah-mudahan Allah membinasakan musuhmu dan menjadikan kamu khalifah di bumi(Nya), maka Allah akan melihat bagaimana perbuatanmu" . perkataan Musa yang seperti ini adalah gambaran seorang pemimpin yang tegas, suatu bimbingan yang menumbuhkan pengharapan. Bahwa bagaimanapun besarnya kekuasaan Firaun itu sekarang, satu waktu dia pasti tumbang.(Hamka, 2003)

Sedangkan Wahbah Zuhaili dalam menafsirkan ayat ini menjelaskan bahwa sudah merupakan bagian dari sifat manusiawi untuk takut dan khawatir dari ancaman penguasa. Maka takutlah Bani Israil karena mereka sebelum kedatangan Musa merupakan orang-orang yang lemah d bawah kekuasaan Firaun. Dan Firaun memungut pajak dari mereka dan mempekerjakan mereka untuk pekerjaan yang sangat berat. Di samping itu Firaun juga menghilangkan segala kesejahteraan dan kemudahan hidup mereka. Ditambah lagi perintah Firaun untuk membunuh setiap bayi laki-laki mereka dan membiarkan hidup bayi perempuan. Maka ketika Musa diutus, Musa menguatkan harapan mereka janji akan menghilangkan segala marabahaya dan kepayahan mereka. Tetapi ketika mereka mendengar bahwa ancaman dari Firaun terus berulang, semakin kuatlah rasa takut dan kesedihan mereka seraya berkata "Kami telah ditindas (oleh Firaun) sebelum kamu datang”. Tetapi Musa bukanlah seorang yang mudah menyerah. Dia tetap membesarkan hati kaumnya dengan harapan bahwa Allah akan 
menghancurkan Firaun dan menjadi kaumnya sebagai pewaris bumi. Dan dengan semua janji yang Allah akan berikan, Allah akan melihat bagaimana mereka tetap berpegang dengan ketaatan kepada Allah dan mensyukuri nikmat dari-Nya.(Zuhaili, 2003)

Ketakutan yang dialami Bani Israel sebagaimana dibabarkan pada ayat dan tafsiran di atas tentu sangat dimaklumi. pada masa itu sebagai bangsa yang dijajah jelas sangat ketakutan dan khawatir tatkala mendapat ancaman dari penguasa yaitu Firaun dengan segala kekuasaannya. Namun sebagai pemimpin kaumnya, Musa tentu saja tidak akan tinggal diam dengan rasa takut dan khawatir yang melanda kaumnya.

Di sinilah kepiawaian Musa dalam memimpin kaumnya kembali terlihat. Sebagai pemimpin dia tidak putus asa dengan keadaan kaumnya yang memang suka mengeluh. Musa membangkitkan rasa optimis dan keyakinan kaumnya dengan harapan besar akan adanya pertolongan Allah yang akan menghancurkan Firaun dan menjadikan Bani Israel sebagai pewaris bumi.

\section{B. Gaya Kepemimpinan Nabi Musa a.s.}

Dalam pembahasan ayat dan tafsir tentang interaksi antara Nabi Musa a.s dan kaumnya Bani Israel, terlihat bahwa Musa memiliki tekad kuat dan sabar dalam menghadapi cobaan, mengingatkan kaumnya untuk selalu bersyukur atas karunia Allah, seorang motivator yang sanggup membangkitkan semangat kaumnya yang berlandaskan keyakinan akan pertolongan Allah.

Sifat dan gaya kepemimpinan Nabi Musa di atas sangatlah cocok untuk memimpin Bani Israel yang memang kala itu dalam posisi yang sedang dijajah, serba lemah dan mudah putus asa. Kepemimpinan Nabi Musa ini menjadi penting mengingat Nabi Musa diutus oleh Allah memiliki dua misi yaitu memimpin pembebasan Bani Israil yang sedang dijajah oleh Firaun dan di waktu yang sama mempunyai misi untuk mendakwahkan tauhid kepada Firaun. Sungguh sebuah misi kenabian yang berat yang hanya dapat dilalui oleh seorang pemimpin yang memiliki daya juang, semangat, tidak mudah menyerah dan motivasi yang tinggi seperti yang dimiliki oleh Nabi Musa a.s.

\section{Implementasi Gaya Kepemimpinan Nabi Musa a.s. dalam Pendidikan Karakter.}

Sebagaimana dijelaskan sebelumnya bahwa karakter setiap manusia tidaklah sama. perbedaan-perbedaan karakter yang terjadi disebabkan manusia diciptakan secara unik, berbeda satu sama lain, dan tidak satu pun yang memiliki ciri-ciri persis sama meskipun mereka itu kembar identik. Setiap individu pasti memiliki karakteristik yang berbeda dengan individu lainnya. (Ali \& Asrori, 2017) 
Perbedaan karakter yang dimiliki setiap orang menurut para ahli psikologi sebagaimana dijelaskan sebelumnya, merupakan bawaan dari kecil dan dari dalam yang dapat digunakan sebagai pembentukan tingkah laku, sikap, dan tabiat yang benar.(Rosyadi, 2013)

Melihat karakter yang masih sangat mudah untuk dibentuk sejak dini, maka perlu untuk menanamkan bagaimana jiwa dan gaya kepemimpinan Musa a.s. agar kepemimpinan positif Musa a.s yang tertulis di dalam Al-Quran dapat diikuti dan dijadikan teladan yang baik. Adapun implementasi gaya kepemimpinan Musa a.s adalah sebagai berikut:

1. Nabi Musa adalah pemimpin yang selalu bersyukur atas karunia Allah dan mengajak kaumnya untuk bersyukur.

Bersyukur kepada Allah merupakan perkara yang sangat penting. Karena tidak bersyukurnya seseorang atas nikmat yang Allah berikan, mengindikasikan kekufuran atas nikmat yang diberikan Allah. Dalam buku Menyucikan Jiwa: Konsep Tazkiyatun Nafs Terpadu Intiasari Ihya Ulumuddin Sa'id bin Muhamamad Daib Hawwa menjelaskan bahwa syukur memiliki tiga dasar:(Hawwa, 2006)

a. Dasar pertama adalah ilmu atau mengetahui bahwa semua kenikmatan yang diterima berasal dari Allah. Dan jika ada keraguan dalam diri bahwa Allah adalah sumber kenikmatan yang diterima, yang terjadi adalah rasa syukur kepada selain Allah.

b. Dasar kedua adalah kondisi spiritual yaitu kegembiraan kepada Pemberi nikmat disertai keadaan tunduk dan tawadu'

c. Dasar ketiga adalah perbuatan sesuai dengan tuntutan kegembiraan yang terjadi dari pengetahuan tentang Pemberi nikmat. Amal perbuatan ini terkait dengan hati, lisan, dan anggota badan. Sehingga dengan hati, lisan, dan perbuatan kita bisa menampakkan rasa syukur baik dengan hati yang bahagia, lisan yang selalu mengucapkan rasa syukur, dan menggunakan kenikmatan tadi untuk taat dan tidak bermaksiat kepada Allah melalui anggota badan. Tiga dasar syukur di atas dapat diimplementasikan kepada peserta didik dengan cara selalu mengajarkan bahwa Allah adalah sumber segala kenikmatan yang diperoleh, dan selalu berbahagia kepada Allah atas nikmat yang diperoleh. Setelah itu mengajarkan kepada anak agar selalu mengucap syukur dengan lisan dan menggunakan nikmat yang digunakan untuk kebaikan dan bukan untuk kemaksiatan. 
2. Nabi Musa adalah pemimpin yang selalu bersabar dalam menghadapi cobaan

Syaikh Muhammad Al-Ghazali dalam buku "Akhlak seorang muslim" menjelaskan bahwa kesabaran merupakan sifat terpuji yang harus dimiliki seorang muslim. Seseorang harus bisa menahan diri untuk menanggung hal-hal yang tidak menyenangkan tanpa disertai keluhan. Dia harus benar-benar memiliki kepercayaan diri, tegar, dan tidak ragu-ragu sekalipun banyak cobaan yang menerpa dirinya. Dia harus tetap yakin kalau pertolongan Allah pasti akan datang. Di antara hikmah keyakinan datangnya pertolongan Allah adalah seseorang akan merasa tenang dan tenteram dalam menantikannya. (Al-Ghazali, 2004) Karakter sabar dalam menghadapi cobaan seperti yang dijelaskan di atas, dapat ditanamkan dalam diri setiap peserta didik dengan terus meyakinkan bahwa di dalam setiap kesabaran seorang muslim, pertolongan Allah pasti akan datang dan setiap kesabaran akan mendatangkan hasil yang melegakan hati.

3. Penuh motivasi, optimis, dan pantang menyerah.

Sebagai seorang pemimpin kaum yang kelak menjadi sebuah bangsa yang besar, Musa selalu memiliki rasa optimis, penuh harapan, dan tidak mudah putus asa atas petunjuk dan pertolongan Allah. Hal ini merupakan sikap seorang pemimpin yang tangguh. Segala kekuasaan dan kekuatan Firaun sebagai seorang penguasa Mesir yang sangat otoriter tidak menggentarkan hati Musa untuk tampil sebagai pemimpin yang bertugas menyelamatkan bangsanya. Keyakinan dan keteguhan hati bahwa hanya dari Allah sajalah kekuatan dan keberanian yang membuat Nabi Musa a.s berani dengan segala keterbatasan yang ada. Rasulullah menjelaskan dalam hadis yang diriwayatkan oleh At-Tirmidzi bahwasanya marabahaya dan manfaat tidak akan menimpa tanpa ketentuan dari Allah dan kita diperintahkan untuk selalu memohon pertolongan hanya kepada-Nya. Karakter Musa ini dapat diimplementasikan kepada peserta didik dengan cara mengadakan berbagai kegiatan yang memicu motivasi dan rasa pantang menyerah seperti berbagai perlombaan, permainan pertandingan, organisasi sehingga terbiasa untuk saling bersaing secara sehat dan penuh motivasi untuk maju. Anak-anak didik pun akan terbiasa untuk menghadapi berbagai tantangan yang ada dan tidak akan mudah menyerah dalam menghadapinya.

\section{KESIMPULAN}

Setelah pembahasan di atas penulis menyimpulkan bahwa gaya kepemimpinan Nabi Musa a.s di dalam Al-Quran adalah sebagai berikut: 
1. Nabi Musa adalah pemimpin yang selalu bersyukur atas karunia Allah dan mengajak kaumnya untuk bersyukur.

2. Nabi Musa adalah pemimpin yang selalu bersabar dalam menghadapi cobaan

3. Penuh motivasi, optimis, dan pantang menyerah.

Adapun implementasi gaya kepemimpinan Nabi Musa a.s di dalam pendidikan karakter, yaitu sebagai berikut:

1. Karakter Nabi Musa yang selalu bersyukur dan mengajak bersyukur dapat implementasikan dengan cara selalu mengajarkan bahwa Allah adalah sumber segala kenikmatan yang diperoleh, dan selalu berbahagia kepada Allah atas nikmat yang diperoleh. Setelah itu mengajarkan kepada anak agar selalu mengucap syukur dengan lisan dan menggunakan nikmat yang digunakan untuk kebaikan dan bukan untuk kemaksiatan.

2. Karakter Nabi Musa yang selalu sabar dalam menghadapi cobaan, dapat ditanamkan dalam diri setiap peserta didik dengan terus meyakinkan bahwa di dalam setiap kesabaran seorang muslim, pertolongan Allah pasti akan datang dan setiap kesabaran akan mendatangkan hasil yang melegakan hati.

3. Karakter Musa yang penuh motivasi, optimis, dan pantang menyerah ini dapat diimplementasikan kepada peserta didik dengan cara mengadakan berbagai kegiatan yang memicu motivasi dan rasa pantang menyerah seperti berbagai perlombaan, permainan pertandingan, organisasi sehingga terbiasa untuk saling bersaing secara sehat dan penuh motivasi untuk maju. Anak-anak didik pun akan terbiasa untuk menghadapi berbagai tantangan yang ada dan tidak akan mudah menyerah dalam menghadapinya.

\section{Daftar Pustaka}

Al-Ghazali, S. M. (2004). Akhlak Seorang Muslim. Jakarta: Mustaqim.

Ali, M., \& Asrori, M. (2017). Psikologi Remaja Perkembangan Peserta Didik. Jakarta: Bumi Aksara.

Ar-rifa'i, M. N. (1999). Ringkasan Tafsir Ibnu Katsir jilid 3. Riyadh: Maktabah Ma'arif.

Halim, A. (2011). Musa Versus Firaun, disadur dari Rusydi al-Badrawi, Musa Wa Harun Qishas al-Anbiya wa at-tarikh dan Muhammad Mutawalli asy-sya'rawi, Qishash al-anbiya. Tangerang: Lentera Hati.

Hamka. (2003). 2003 Tafsir Al-Azhar Jilid 4. Singapura: Pustaka Nasional PTE LTD. 
Implementasi Gaya Kepemimpinan Nabi Musa A.S dalam Pendidikan Karakter

Hawwa, S. bin M. D. (2006). Mensucikan Jiwa: Konsep Tazkiyatun Nafs Terpadu Intisari Ihya Ulumuddin. Jakarta: Robbani Press.

Kartono, K. (2010). Pemimpin dan Kepemimpinan, Apakah Kepemimpinan Abnormal Itu. Jakarta: Raja Grafindo Persada.

Kilmah, T. B. (2013). Ensiklopedia Pengetahuan Al-Quran dan Hadits jilid 7. Jakarta: Kamil Pustaka.

Meyer, P. J. (2008). 5 Pilar Kepemimpinan Bagaimana Menjembatani Kesenjangan Kepemimpinan, diterjemahkan oleh Hadi Kristiadi. Jakarta: Raja Grafindo Perkasa.

Nata, A. (2002). Tafsir Ayat-ayat Pendidikan (Tafsir Al-Ayat Al-Tarbawy). Jakarta: Raja Grafindo Persada.

Quthb, S. (2008). Tafsir Fi Zhilalil Quran di bawah naungan Quran (jilid 7).

Rosyadi, H. A. R. (2013). Pendidikan Islam Dalam Pembentukan Karakter Anak Usia Dini (Konsep dan Praktik PAUD Islami). Jakarta: Raja Grafindo Persada.

Syafri, U. A. (2014). Pendidikan Karakter Berbasis Al-Quran. Jakarta: Raja Grafindo Persada.

Yusanto, M. I. (2011). Menggagas Pendidikan Islami. Bogor: Al-Azhar Press.

Zuhaili, W. (2003). Tafsir Al-Munir jilid 5. Damaskus: Darul Fikri. 